\title{
PENGARUH BERBAGAI DOSIS UMBI GADUNG RACUN (Dioscorea hispid) TERHADAP KEMATIAN TIKUS MENCIT PUTIH (Mus musculus strain albino)
}

\author{
Ari Rahmawati'), Arif Widyanto ${ }^{2)}$ \\ Jurusan Kesehatan Lingkungan, Politeknik Kesehatan Kemenkes Semarang, \\ Jl.Raya Baturaden KM 12 Purwokerto, Indonesia
}

\begin{abstract}
(The effect of various doses of yam tubers (Dioscorea hispida) to the death of white mice rats (Mus musculus strain albino) Rats are one of the wildlife that become pests that interfere in people's lives. Control mice had pretty much done by the community, both physically and chemically. On of them is using natural plants containing toxins. An example is the yam tuber containing compounds that are toxic dioscorine toxic. This research used an experimental method in laboratory. Research carried out by the feed method. Shaped bait pellets made from fish powder, bran, pecan and yam tubers.Rats were divided 4 groups were placed into containers esch containing 6 rats based doser 250 gram, 500 gram and 750 gram. The study was conducted for 48 hours. For other researchers will continue if a similar study should not be mixed rat but the split is a rat placed in one container to make it easier and more effective observations
\end{abstract}

Keywords : White Mice Rats, Yam Tubers

\begin{abstract}
Abstrak
Tikus merupakan salah satu satwa liar yang menjadi hama yang mengganggu dalam kehidupan manusia. Pengendalian tikus sudah cukup banyak dilakukan oleh masyarakat baik secara fisik maupun secara kimia. Salah satunya dengan memanfaatkan tumbuhan alami yang mengandung racun, contohnya adalah umbi gadung yang mengandung senyawa dioskorin yang bersifat toksik. Penelitian ini menggunakan metode eksperimental di laboratorium. Penelitian dilakukan dengan metode umpan. Umpan dibuat berbentuk pelet dari tepung ikan, dedak, kemiri dan umbi gadung. Tikus dibagi menjadi 4 kelompok yang ditempatkan ke dalam kontainer, masing- masing kontainer berisi 6 ekor berdasarkan dosis umbi gadung yaitu 250 gram, 500 gram dan 750 gram. Penelitian dilakukan selama 48 jam. Penelitian ini menggunakan metode eksperimental di laboratorium. Penelitian dilakukan dengan metode umpan. Umpan dibuat berbentuk pelet dari tepung ikan, dedak, kemiri dan umbi gadung. Tikus dibagi menjadi 4 kelompok yang ditempatkan ke dalam kontainer, masing- masing kontainer berisi 6 ekor berdasarkan dosis umbi gadung yaitu 250 gram, 500 gram dan 750 gram. Penelitian dilakukan selama 48 jam. Untuk peneliti yang lain jika akan melanjutkan penelitian yang serupa sebaiknya tikus tidak dicampur namun dipisah-pisah yaitu satu tikus diletakkan dalam satu kontainer agar lebih mudah dalam pengamatannya dan lebih efektif.
\end{abstract}

Kata kunci : Tikus Mencit Putih; Umbi Gadung

\section{PENDAhUluAN}

Tikus adalah hewan mengerat (rondensia) yang lebih dikenal sebagai hama tanaman pertanian, perusak barang digudang dan hewan penggangu yang menjijikan di perumahan. Belum banyak diketahui dan disadari bahwa kelompok hewan ini juga membawa, menyebarkan dan menularkan berbagai penyakit kepada manusia, ternak dan hewan peliharaan. Penyakit tersebut dapat ditularkan kepada manusia secara langsung oleh ludah, urin dan fesesnya atau melalui gigitan ektoparasitnya (kutu, pinjal, caplak dan tungau).

Sebagai langkah dalam upaya mencegah kemungkinan timbulnya penyebaran penyakit serta untuk mencegah timbulnya kerugian sosial dan ekonomi yang tidak diharapkan, maka perlu disusun pedoman teknis pengendalian tikus. Pengendalian tikus dapat dilakukaan dengan cara biologis, mekanik dan fisik. Pengendalian secara biologis dapat dilakukan dengan cara memasang perangkap, secara mekanik dapat dilakukan dengan cara yaitu memburu tikus dengan menghancurkan atau membongkar sarang-sarang tikus. Biasanya dari sarang tersebut tikus akan keluar. Selain pembongkaran, cara lain untuk mengeluarkan tikus dari sarangnya dengan pengasapan belerang, dan pengendalian secara fisik dapat dilakukan dengan cara pemasangan perangkap dan dengan menggunakan umpan.

Salah satu alternatifnya adalah dengan penggunaan rodentisida nabati, yaitu suatu umpan 
beracun dengan menggunakan bahan tanaman yang mudah ditanam dan mudah diperoleh oleh petani. Penggunaan rodentisida nabati tidak dimaksudkan untuk mengganti atau menggeser penggunaan rodentisida sintetis. Rodentisida nabati hanyalah salah satu alternatif pengendalian, khususnya di daerah yang relatif terisolir, dikalangan petani dengan modal terbatas, atau pada keadaan rodentisida sintetis sulit diperoleh.

Dua jenis tumbuhan yang sering digunakan sebagai rodentisida nabati adalah gadung $\mathrm{KB}$ dan gadung racun. Penelitian semacam ini sebelumnya pernah dilakukan oleh seorang mahasiswa Universitas Diponegoro bernama Patriawati Narendra (E2A303148) pada skripsinya pada tahun 2005, "Daya Bunuh Gadung Racun Terhadap Mencit Putih". Dalam penelitinnya tersebut, umbi gadung yang digunakan terlebih dahulu dijadikan ekstrak. Tanaman ini mengandung senyawa beracun yang bernama dioskorin, yang merupakan salah satu senyawa alkaloid yang bersifat racun terhadap tikus.

Umpan merupakan salah satu cara pengendalian tikus yang pengaplikasiannya mudah dan dapat dibuat sendiri dengan menggunakan bahan alami beracun. Namun tikus merupakan hewan yang jera umpan. Untuk menyiasati hal ini, pembuatan umpan beracun perlu memadukan bahan alami beracun yang dicampur dengan makanan kesukaan tikus.

Untuk itu perlu dilakukan penelitian guna mengetahui efektivitas umbi gadung racun (Dioscorea hispida) sebagai rodentisida terhadap kematian tikus mencit putih (Mus musculus strain albino) dengan metode pengendalian fisik berupa umpan.

\section{BAHAN DAN METODE}

Bahan- bahan yang digunakan dalam penelitian ini adalah umbi gadung racun (Dioscorea hispida), dedak, tepung ikan, dan kemiri. Umbi gadung racun (Dioscorea hispida) dibagi menjadi 4 dosis yaitu 0 gram, 250 gram, 500 gram dan 750 gram sedangkan untuk dedak masing- masing sebanyak 150 gram, tepung ikan sebanyak 100 gram, 100 gram, 350 gram, dan 600 gram dengan kemiri masing- masing 5 butir, 5 butir, 10 butir dan 15 butir. Jumlah tikus sebanyak 24 ekor dibagi menjadi 4 kelompok kontainer dengan jumlah perkelompok kontainer berisi 6 ekor tikus. Alat yang diperlukan antara lain timbangan analitik, pisau dan mortar. Metode penelitian ini menggunakan metode eksperimen yaitu berupa pengendalian fisik menggunkan umpan dengan metode analisis berupa analisis tabel. Umpan dibuat dengan mencampur semua bahan dengan terlebih dahulu menimbang umbi gadung sesuai dengan dosis yang telah ditentukan lalu ditumbuk hingga halus. Untuk selanjutnya di bentuk bulat menyerupai pelet dan dijemur. Setelah kering pelet tersebut langsung dapat di aplikasikan kepada tikus. Waktu pengamatan dibagi menjadi 3 periode waktu yaitu pengematan pertama pada 12 jam, pengamatan kedua pada 24 jam dan pengamatan ke tiga pada 48 jam.

\section{III.Hasil dan Pembahasan}

Tabel 4.1 : Hasil Pengukuran Parameter Kondisi Lingkungan Fisik Laboratorium Entomologi

\begin{tabular}{lllll}
\hline No & $\begin{array}{c}\text { Tanggal } \\
\text { Percobaan }\end{array}$ & Suhu & $\begin{array}{c}\text { Kelemba } \\
\text { ban }\end{array}$ & $\begin{array}{c}\text { Penca } \\
\text { hayaan }\end{array}$ \\
\hline 1 & 12 Juni 2015 & $26^{\circ} \mathrm{C}$ & $80 \%$ & 135 Lux \\
\hline 2 & 12 Juni 2015 & $26,5^{\circ} \mathrm{C}$ & $80 \%$ & 135 Lux \\
\hline 3 & 12 Juni 2015 & $26^{\circ} \mathrm{C}$ & $80 \%$ & 135 Lux \\
\hline
\end{tabular}

Tabel 4.2 : Hasil Kematian Tikus

\begin{tabular}{cccccc}
\hline \multirow{2}{*}{ No } & \multirow{2}{*}{ Dosis } & \multicolumn{3}{c}{ Kematian Tikus (Ekor) } & \multirow{2}{*}{ Jumlah } \\
\cline { 3 - 5 } & & 12 jam & 24 jam & 48 jam & \\
\hline 1 & 0 gram & 0 & 0 & 0 & 0 \\
\hline 2 & 250 gram & 0 & 0 & 0 & 0 \\
\hline 3 & 500 gram & 0 & 1 & 0 & 1 \\
\hline 4 & 750 gram & 0 & 3 & 0 & 3 \\
\hline \multicolumn{2}{c}{ Jumlah } & 0 & 4 & 0 & 4 \\
\hline
\end{tabular}

Analisis tidak dapat dilakukan dengan analisis varian karena data tidak homogen dan kurang adanya variasi data. Dengan demikian maka data hanya dapat di analisis menggunakan analisis tabel. Adapun hasil analisis tabel 4.2 tentang Hasil Kematian Tikus adalah :

a. Kematian tikus tidak terjadi pada waktu 12 jam percobaan.

b. Kematian tikus terjadi pada waktu 24 jam percobaan dengan dosis umbi gadung 500 gram tikus yang mati 1 ekor dan dosis umbi gadung 750 gram tikus yang mati 3 ekor.

c. Kematian tikus tidak terjadi pada waktu 48 jam percobaan

Umpan yang digunakan dalam penelitian ini merupakan campuran dari tepung ikan yang dibuat langsung dengan cara mengoven ikan lalu di hancurkan sampai menjadi tepung, lalu ditambah dedak, kemiri dan gadung sebagai racunnya. Pembuatan umpan ini mengacu pada kesukaan makan tikus yang cenderung menyukai makanan yang berbau tajam seperti ikan.

Setiap kontainer yang berisi 6 ekor tikus masingmasing di beri umpan sebanyak 100 gram dengan konsentrasi umbi gadung yang berbeda- beda. Sebelum dilakukan pengumpanan tikus terlebih dahulu di puasakan selama 24 jam. Penelitian dilakukan dengan cara mengumpankan langsung umpan tersebut. Waktu penelitian di bagi tiga berdasarkan lamanya waktu yang digunakan yaitu penelitian satu selama 12 jam, penelitian dua selama 24 jam dan penelitian tiga selama 48 jam.

Penelitian dimulai pada hari jumat 12 juni 2015 pukul 18.00 WIB - 06.00 WIB sabtu 13 juni 2015. Dari penelitian tersebut di peroleh hasil bahwa tidak ada tikus yang mati. Dilanjutkan penelitian kedua dengan menambah waktu penelitian selama 6 jam 
yaitu hari sabtu 13 juni 2015 pukul 06.00 WIB 18.00 WIB. Adapun hasil dari penelitian tersebut ternyata ada 4 ekor tikus yang mati. Adapun tikus yang mati adalah dari kontainer ke 3 dengan jumlah tikus yang mati sebanyak 1 ekor dan kontainer 4 dengan jumlah tikus yang mati sebanyak 3 ekor . Dilanjutkan dengan penelitian ketiga dengan menambah waktu 12 jam lagi yaitu dimulai dari hari sabtu 13 juni 2015 pukul 18.00 WIB - 18.00 WIB minggu 14 juni 2015.

Adapun dari hasil penelitian terakhir adalah tidak ada tikus yang mati.

Dari hasil penelitian yang telah dilakukan di atas maka :

1. Tikus memakan umpan yang disediakan, hal ini ditandai dengan berkurang nya jumlah umpan yang terdapat di masing- masing kontainer.

2. Kontainer 1 yaitu pada kontrol, tikus memakan separuh umpan yang disediakan. Walaupun tikus dalam kontainer 1 memakan cukup banyak umpan mereka tidak akan mati karena umpan tersebut tidak di campur dengan umbi gadung, melainkan hanya terdiri dari tepung ikan, dedak dan kemiri.

3. Kontainer 2 yaitu dengan konsentrasi umbi gadung sebanyak 250 gram. Tikus hanya memakan sepertiga umpan yang disediakan. Walaupun umpan telah dimakan sedikit hal ini tidak membuat tikus- tikus tersebut mati dikarenakan dosis umbi gadung yang digunakan masih rendah.

4. Kontainer 3 yaitu dengan konsentrasi umbi gadung sebanyak 500 gram. Tikus hanya memakan sepertiga umpan yang disediakan. Namun demikian ada 1 ekor tikus yang mati dalam 24 jam waktu penelitian.

5. Kontainer 4 yaitu dengan konsentrasi umbi gadung sebanyak 750 gram. Tikus hanya memakan seperempat umpan yang disediakan. Namun demikian terdapat 3 ekor tikus yang mati dalam waktu 24 jam masa penelitian. Hal ini menunjukan bahwa tikus mati karena memakan umpan, dikarenakan umpan tersebut mengandung dosis umbi gadung yang cukup tinggi, maka tikus- tikus yang mati tersebut telah teracuni oleh umbi gadung tersebut.

6. Setelah 24 jam ada 4 ekor tikus yang mati. Namun setelah penelitian dilanjutkan sampai 48 jam tidak ada satu ekorpun tikus yang mati. Hal ini disebabkan oleh tikus- tikus lain yang belum mati setelah tau ada tikus lain yang mati maka tikus- tikus yang masih hidup tersebut tidak memakan umpan yang di sediakan. Hal ini sesuai dengan sifat tikus yang merupakan binatang yang cukup cerdas. Dan tikus juga tahan hidup tanpa makanan dalam kurun waktu yang lama. (Rochman. 1992). Hal lain yaitu apabila tikustikus tersebut sama- sama makan namun ada tikus yang mati dan ada yang masih hidup, kemungkinan di pengaruhi oleh berat badan tikus. Dimana berat badan berpengaruh terhadap daya tahan hidup tikus. Semakin kecil ukuran tubuh tikus, maka daya tahan tubuh tikus tersebut terhadap racun semakin rendah. Hal ini terbukti dengan tikus- tikus yang mati semuanya berukuran lebih kecil dari pada tikus yang masih hidup.

7. Maka kemungkinan bahwa ke 4 ekor tikus yang mati itu disebabkan benar- benar makan umpan.

\section{IV.KESIMPULAN}

Berdasarkan hasil penelitian yang telah dilakukan dapat disimpulkan sebagai berikut :

1. Ada pengaruh penggunaan berbagai dosis umbi gadung terhadap kematian tikus mencit putih (Mus musculus strain albino ). Dosis umbi gadung 750 gram merupakan dosis yang menyebabkan kematian tikus dengan jumlah kematian terbanyak yaitu 3 ekor, sedangkan dosis 500 gram merupakan dosis yang menyebabkan kematian 1 ekor dan pada dosis 250 gram tidak menyebabkan kematian.

2. Terdapat perbedaan kematian tikus mencit putih (Mus musculus strain albino) setelah penggunaan berbagai konsentrasi umbi gadung yaitu antara dosis umbi gadung 750 gram sebanyak 3 ekor dan dosis umbi gadung 500 gram sebanyak 1 ekor.

3. Dosis 750 gram lmerupakan dosis yang paling efektif untuk membunuh tikus mencit putih (Mus musculus strain albino) setelah adanya perlakuan selama 48 jam.

\section{DAFTAR PUSTAKA}

Budiman Chandra. (2005). Pengantar Kesehatan Lingkungan. Jakarta : EGC.

Chasan S Kusnadi. (2006). Pengendalian Vektor dan Binatang Pengganggu, Makasar : Instalasi Penerbitan Jurusan Kesehatan Lingkungan Politeknik Kesehatan Makasar.

Direktorat Perlindungan Tanaman Pangan. "Kebijaksanaan dan Program Pengendalian Hama Tikus". makalah pada Lokakarya Tikus di Bandungan, Jawa Tengah (Jakarta : 1985).

Kardinan, Agus. (2000). “ Pestisida Ramuan dan Aplikasinya” . PT. Penebar swadaya, Jakarta, at http://www.lazuardihigh.sch.id/2014/11/pemanfaatan-umbigadung-dioscorea.html, di akses pada tanggal 15 Februari 2015.

Narendra, Partriawati. (2005). "Daya Bunuh Gadung Terhdap Mencit Putih, Semarang”. Skripsi. Semarang: Fakultas Pertanian, Universitas Diponegoro, at http://eprints.undip.ac.id/35606/5/Bab_4.pdf, di akses pada tanggal 30 Juli 2015. 
Rochman. "Biologi dan Ekologi Tikus" . Prosiding Seminar Pengendalian Hama Tikus Terpadu, hal. 17-30 (Bogor : 1992).

Sipayung, A. "Prospek dan Efektivitas Pengendalian Hayati Tikus" . Prosiding Seminar Pengendalian Hama Tikus Terpadu, hal.57-65 (Bogor : 1992), at http://www.academia.edu/9278499/Pengaruh_
Pemberian_Pelet_Umbi_Gadung_Terhadap_J umlah_Spermatozoa_Mencit, di akses 17 Februari 2015.

Untung, K. Pengantar Pengelolaan Hama Terpadu, (Yogyakarta : Gadjah Mada University Press, 1993). 